WIDER Working Paper 2018/25

\title{
Diaspora externalities
}

A view from the South

Hillel Rapoport*

February 2018 
Abstract: Migration decisions affect those left-behind in ways that are partly taken into account by market forces (e.g., wage effects on labour markets) and for the most part these can be seen as pure externalities. Diasporas are an example of such an externality. This paper reviews the recent economic literature on diaspora networks and development from the perspective of the global South. It is split into two parts: a first section reviews the effect of diaspora networks on trade, foreign investments, and the diffusion of knowledge as well as technology across borders. A second section looks at the cultural sway of the diaspora, investigating on a macro-level the role of migration in cultural convergence across countries and on a micro-level the impact of emigrants in the formation of political attitudes, fertility behaviour, and other aspects of culture.

Keywords: diaspora networks, international migration, development, brain drain, trade, FDI, knowledge diffusion, social remittances, cultural integration

JEL codes: F21, F22, F63, J61, O11, O15

\footnotetext{
* Paris School of Economics, University Paris 1 Pantheon-Sorbonne, and CEPII, email: Hillel.Rapoport@univ-paris1.fr.
}

This research study is released in connection with the WIDER Development Conference on 'Migration and Mobility - new frontiers for research and policy', jointly organized with the African Research Universities Alliance (ARUA), on 5-6 October 2017 in Accra, Ghana. It largely builds on previous published work by the author, notably Rapoport $(2016,2017)$.

Copyright (C) UNU-WIDER 2018

Information and requests: publications@wider.unu.edu

ISSN 1798-7237 ISBN 978-92-9256-467-4 https://doi.org/10.35188/UNU-WIDER/2018/467-4

Typescript prepared by Ans Vehmaanperä.

The United Nations University World Institute for Development Economics Research provides economic analysis and policy advice with the aim of promoting sustainable and equitable development. The Institute began operations in 1985 in Helsinki, Finland, as the first research and training centre of the United Nations University. Today it is a unique blend of think tank, research institute, and UN agency — providing a range of services from policy advice to governments as well as freely available original research.

The Institute is funded through income from an endowment fund with additional contributions to its work programme from Finland, Sweden, and the United Kingdom as well as earmarked contributions for specific projects from a variety of donors.

Katajanokanlaituri 6 B, 00160 Helsinki, Finland

The views expressed in this paper are those of the author(s), and do not necessarily reflect the views of the Institute or the United Nations University, nor the programme/project donors. 
People make decisions as to whether to migrate based on the costs and benefits they expect for themselves and for their loved ones. Individual migration decisions affect those left-behind in ways that are for some part taken into account by market forces (e.g., wage effects on labour markets); for the most part however, emigration affects the current and future growth of source countries in ways that can be seen as pure externalities, that is, unintended consequences of individual decisions that are not reflected (at least not directly) through market prices. This is how the 'brain drain', for example, has been portrayed in the early literature of the 1970s as well as in the first 'new growth' models of the early 1990s. And this also applies, this paper will argue, to the role of migration and diaspora networks that contribute to integrate home countries into the word economy. While by definition individuals do not internalize the full extent of consequences of their decisions on others' welfare (for if they were, there would be no externality), these consequences should be-but are seldom—accounted for in policy making.

Externalities can be positive or negative. Accordingly, externalities arising from emigration can be good or bad for the development of home countries. Some well-known arguments for the negative externalities of emigration include that emigrants can fuel civil conflicts, or that remittances can act as a driver of 'Dutch Disease'; that is, the inflow of foreign currency (through remittances), similarly to the discovery of a natural resource, can lead to a real exchange rate appreciation of the local currency, thus weakening the local economy as production and exports become less competitive. One of the classical concerns about the negative effects of emigration is the so called 'brain drain'. An increasing fraction of South-North migration is highly-skilled. The number of college-educated immigrants born in a developing country and living in an OECD host country has more than doubled between 1990 and 2000 (Beine et al., 2007) and now represents more than 40 per cent of South-North migration. This explosion in the numbers has not depleted too much the stock of human capital remaining in developing countries: the intensity of the brain drain has only slightly increased in most regions (and even decreased in some), mostly thanks to strong progress in educational attainments worldwide. The early literature on the effect of emigration on human capital accumulation, however, promoted the idea that there are negative externalities on those left behind (Bhagwati and Hamada 1974, Miyagiwa 1991), suggesting that brain drain can represent a substantial impediment to developing countries' growth prospects (Todaro 1996).

However, the more recent literature has re-approached the issue of brain drain and found positive spill-overs and incentive-creating effects of migration on educational attainment (Beine et al. 2001, 2008; Mountford 1997). ${ }^{1}$ In fact, these papers propose the 'incentive effect' as a possible channel of brain gain: the prospect of migration motivates people to accumulate human capital in order to increase their chances to successfully emigrate. To discuss this idea let me use the metaphor of a cake (the country's stock of human capital), with the brain drain being traditionally presented as equivalent to cutting a piece of the cake (say a quarter) and sending it abroad - hence the loss. This view neglects two things. First, those abroad form a diaspora which can keep interacting with the home country in many economically useful ways. I will discuss diaspora links in more detail in the following section. And second, this view fails to ask how the cake was made. The truth, however, is that the size of the initial cake, the one from which the piece is taken, is bigger when there are more emigration options. Or, in economists' jargon, the stock of human capital is endogenous to

\footnotetext{
${ }^{1}$ See Gibson and McKenzie (2011) and Docquier and Rapoport (2012) for overviews of the recent brain drain literature, and Chand and Clemens (2008) and Shresta (2017) for micro-studies supporting the beneficial brain drain hypothesis using natural experiments.
} 
migration. The brain drain may in fact consist in cutting a piece of the human capital cake, but from a bigger cake than the one that would exist if there was no brain drain.

Beyond the brain drain/gain question, there are many externalities linked to the presence of diaspora networks in the host countries. On the one hand, diaspora networks can help their home countries to integrate more into the global economy. In this paper, I will discuss how migrant networks contribute to bilateral trade, investments and other financial flows as well as to the diffusion of knowledge and technology between home and host countries. On the other hand, diaspora networks can have an effect that is not purely economic but also cultural, through 'social remittances', that is, migrants' transfers of behavioural and cultural norms to their home communities. The concept of social remittances builds on the idea that while abroad, migrants absorb new information and are exposed to new attitudes, preferences, and practices that can first transform them and then spill over to their home communities through direct and indirect contacts with relatives, friends and other members of their home-based social networks. These social remittances include political values, fertility norms, religious attitudes and practices, etc.

The paper, therefore, is split into two parts: the first part reviews the effect of diaspora networks on trade, foreign investments, other financial flows, and the diffusion of knowledge as well as technology across borders. The second section will look at the cultural sway of the diaspora, investigating on a macro-level the role of migration in cultural convergence across countries and on a micro-level the impact of emigrants in the formation of political attitudes, fertility behaviour, and other aspects of culture.

\section{Economic integration into the global economy}

\subsection{The trade-creating effect of migration}

\section{Cross-country evidence}

Migration can be an important factor in integrating developing countries into the global economy, particularly through its effect on the trade in goods and services between host and home countries. In fact, recent literature in the field of international trade shows that migration networks have strong trade-creating effects. There are at least two channels through which immigration has been shown to affect trade flows. The first mechanism is related to an information effect: immigrants can increase bilateral imports and exports because they help overcoming information problems thanks to their having a better knowledge of their origin and host-country markets, the connections and knowledge about the respective institutional and business environments, as well as the linguistic skills that are needed to start and develop import and export activities across countries. Previous literature has mainly focused on this effect by showing that the role of ethnic networks is more important for differentiated than for homogenous products (see for instance Felbermayr and Toubal, 2012, Rauch and Trindade, 2002; and Rauch and Casella, 2003.). The idea behind this mechanism is that ethnic networks are likely to reduce information costs - for instance, through more efficient matching and referral services - and these costs are likely to be larger for differentiated goods. The second channel through which immigration can affect trade flows is a preference effect (also denoted as 'ethnic-goods' channel). Immigrants can generate additional demand for goods from their source countries, both directly, through their own consumption (as when, in their utility function, they attach a higher weight to the consumption of products from their origin country), or indirectly, by affecting natives' preferences (through a diffusion of preferences effect). 
Gould (1994) analyses how immigrant links influence bilateral trade flows in the United States, using 47 US trading partners between 1970 and 1980. The author proposes three channels through which immigrant links can decrease the transactions costs. First, the native language of the immigrants will be more spread in the host country, which diminishes the trading costs due to communication barriers. Second, the costs of obtaining foreign market information in the host country will decrease, as immigrants bring information about their home-country products and preferences. Third, particularly in developing countries with weak institutions and risk of not enforcing contracts, the development of trust through immigrant contacts can decrease the costs associated with negotiating trade contracts.

The author finds a strong association between the size of the immigrant community and bilateral trade between the US and their home countries. A one per cent increase in the stock of migrants is associated with an increase in bilateral trade, with the largest effects being in aggregate and consumer manufactured exports. Gould illustrates his results with the example of Singaporean and Philippine immigrants, showing that an additional immigrant from Singapore has the largest potential to generate new trade, with additional imports at a value of US $\$ 29,359$ per year and exports at a value of US $\$ 47,708$. On the other hand, an additional immigrant from the Philippines would create only about US $\$ 6$ of imports per year and US $\$ 4$ of exports. Moreover, the longer the stay of immigrants in the USA, the smaller their effect on bilateral trade and there is no systematic evidence that the trade-generating effect of immigration differs by skill level.

Similarly, Head and Ries (1998) show that immigrants may expand trade with their country of origin, using Canadian trade data with 136 partners from 1980 to 1992. The authors propose the information effect as a main channel with immigrants owning superior knowledge of, or preferential access to, market opportunities. In terms of magnitude, the results for Canada from their augmented gravity estimation are smaller than for the United States: a 10 per cent increase in immigrants is associated with a 1 per cent increase in Canadian exports to the immigrant's home country and a 3 per cent increase in imports. Additionally, the authors examine different classes of immigration such as refugees, family migration, entrepreneurs, independents, and other businessclass immigrants. Families and independents exhibit the strongest effects on bilateral trade, and contrary to the empirical and theoretical findings by Rauch and Trindade (2002) and Rauch and Casella (2003), the authors find weaker effects for entrepreneurs and business-class immigrants. The authors explain this result with the selection of immigrants in these classes. Business immigrants are admitted to Canada primarily because of capital (investors) or because they are artists (self-employed) and therefore do not bring trade knowledge or connections to Canada. Entrepreneur-class immigrants receive a 45-point (out of 70 ) bonus which may allow many to enter despite low scores on the other selection criteria.

Combes et al. (2005) bring this analysis to an intra-national setting to isolate networks effects from other explanations of trade and look at the role of business and social networks in shaping trade between 94 French regions. The impact of social networks is quantified using bilateral migrant stocks and business network effects are assessed by using data on the links between plants belonging to the same business group. The authors estimate the trade-creating effect of business and social ties on bilateral trade based on a traditional gravity equation and expand the estimation to a 'structural' specification directly derived from a model of trade characterized by monopolistic competition, home-biased preferences, information and transport costs.

The authors find that compared to a situation without networks, the average bilateral migrant population doubles trade flows between French regions. However, this effect is small compared to the effect of links between plants belonging to the same business group. These links multiply trade flows by as much as five. This difference in magnitude supports their hypothesis that business and social ties mostly decrease trade costs through facilitated access and transmission of 
information. Additionally, the authors caution that the trade-depressing role of traditional trade costs (such as transport costs, administrative borders and non-contiguity) is largely overestimated if network effects are not controlled for.

In many instances, therefore, trade and migration appear as complements. While these studies provide evidence that migration networks have trade-creating effects, they do not consider specifically highly skilled migrants. An exception is Felbermayr and Jung (2009), who use bilateral panel data on trade volumes and South-North migration to OECD countries. The authors present three major results. First, failing to control for unobserved heterogeneity indeed leads to overestimation. Second, there is, nevertheless, a statistically and economically significant causal effect of migration on trade: a one-per cent increase in the bilateral stock of migrants raises bilateral trade by 0.11 per cent. Third, low- and high-skilled migrants strongly boost bilateral trade by comparable quantities while medium-skilled migration does not seem to matter. Koenig (2009) confirms the trade-creating effect using firm-level data on French exports. She shows that this effect is enhanced when immigrants are older and more educated.

Finally, Aleksynska and Peri (2014) use a more carefully defined measure of migration business networks to quantify its impact on bilateral trade and to shed light on the information effect of migration on trade. Using data on immigrant occupations from OECD (2010), the DIOC-E database, the authors consider in each country those immigrants in managerial/sales jobs that are pivotal to establishing business connections. The authors find that the share of immigrants in business network occupations shows a particularly large effect on trade in differentiated goods and encourages exports to culturally different countries, such as those with different language and legal origin.

\section{Evidence from natural experiments}

The above studies all use bilateral data on trade and migration to analyse the effect of the latter on the former, relying mostly on the time-structure of the data (that is, using migration networks formed long before the trade flows analysed took place) for identification, as well as on a rich set of heterogeneous effects (e.g., homogeneous v. heterogeneous goods, imports v. exports, skilled v. unskilled migrants) that constitute both plausibility tests and allow for richer interpretation of the results. The suspicion, however, is that there may be bilateral omitted factors that drive the joint pattern of trade and migration that may be time-invariant (and, hence, not addressed when using lagged values); or, for firm-level data, that forward-looking firms planning to expand their activities in certain countries would recruit workers from these countries ahead of their trade expansion. It could also be that migration affects trade through FDI, an issue we will address in the next section.

What the literature was really lacking until recently, therefore, is a natural experiment allowing to gauge the trade-creating effects of migration in a way that could address the above concerns. This is now available thanks to the work of Parsons and Vezina (2017), who confirm the trade-creating effect of migration using the natural experiment of the Vietnamese boat people. These refugees were randomly assigned residence in the US after the fall of Saigon in 1975 and spent their first years in the US at a time the US had an embargo on trade with Viet Nam. The networks formed at that time proved instrumental in fostering US exports to Viet Nam after the embargo was lifted in the mid-1990s, with US States with larger networks consistently exporting more to Viet Nam than States which received lower amounts of Vietnamese refugees. The authors convincingly show that the allocation of refugees across US States can be considered exogenous (and certainly independent of future trade links with Viet Nam) and that all of the effect can be attributed to trade in heterogeneous goods, which is suggestive of the role of networks in removing information barriers. 
Steingress (2015) performs a similar exercise on a larger scale, using various wages of refugees to the US as natural experiments; not just forced displacement refugees out of war-torn countries such as Viet Nam in the 1970s, but also displacements due to weather shocks and natural disasters that plagued Central American countries (earthquakes in San Salvador, hurricane Mitch). He finds that a 1 per cent increase in recent immigration to a given US state will increase imports to that state by 1.2 per cent and its exports to the migrants' home country by 0.5 per cent. In examining the potential channel for the trade-creating effect of migration, he finds evidence for both the information and the preference effect. Distinguishing between differentiated ('luxury goods') and homogeneous goods ('necessity' goods) and assuming that the role of migrants as a force to reduce information frictions is stronger for differentiated products, Steingress (2015) finds a pro-trade effect of migration, on the exports side, only for differentiated goods. Additionally, he finds a positive effect of immigration on the import of differentiated goods as well, a finding he attributes to the preference effect of immigrant networks. To further test the channels, Steingress subsumes different immigrant groups under larger categories. To test the transaction cost channel, he uses the following grouping variables: sharing a common legal origin and sharing a common official language. For the preference effect, he hypothesizes that preferences between countries are more similar to each other if the respective countries share a common border. His empirical results show that immigrants with common legal origin increase only exports whereas immigrants, who share a common border or language, increase imports of the related country. This evidence seems to suggest that immigrants increase the exports of a US state by providing information about the legal system when contracting in the related country. Sharing a common language or a border does not increase exports, although they generate import demand, which is consistent with both channels.

\subsection{Migration and financial investments}

The third component of globalization, and maybe the most impressive one in terms of recent decades' expansion is the worldwide liberalization of financial investments. These include Foreign Direct Investments (FDI), be it 'greenfield' or through merger and acquisitions, and other crossborder financial flows such as bank loans or the purchase of foreign bonds and equities. The same transaction cost argument that was deployed for the trade-creating effect of migration can be extended to international investments. If anything, the argument is even more relevant for two reasons. First, FDI involve important fixed costs; these will be incurred only after the institutional context and legal framework of the targeted destination country have been carefully studied and local business and sometimes political connections have been established. Second, in the case of financial flows such as portfolio assets, it has long been recognized that the strong 'home bias' that characterizes domestic portfolio structures is largely due to information frictions. Compared to trade, an additional insight from recent studies is that skilled migrants are likely more able to supply the type of information, and the type of connections, required to alleviate information asymmetries and frictions.

As for trade, investigations of the links between migration and FDI started with US FDI outflows to the rest of the world (Foley and Kerr, 2012, Javorcik et al., 2011, Kugler and Rapoport, 2007,) and with the role of ethnic Chinese networks in promoting bilateral FDI between countries equipped with a large Chinese diaspora (Tong, 2005). For example, Kugler and Rapoport (2007) used bilateral data on US FDI outflows (disaggregated for manufacturing v. services) and US Census immigration data (disaggregated by skill levels) and found that US manufacturing FDI toward a given country are negatively correlated with current low-skill migration, while FDI in both the service and manufacturing sectors are positively correlated with the initial US high-skill immigration stock of that country. Javorcik et al. (2011) confirm these results after instrumenting for migration using passport costs and migration networks with a 30-year lag. Finally, Foley and Kerr (2012) quantify firm-level linkages between high-skill migration to the USA and US FDI in the sending countries. They combine US firm-level data on FDI and on patenting by ethnicity of 
the investors and find robust evidence that firms with higher proportions of their patenting activity performed by inventors from a certain ethnicity subsequently increase their FDI to the origin country of the inventors. They find that a 1 per cent increase in the extent to which a firm's pool of inventors is comprised of a certain ethnicity is associated with a 0.1 per cent increase in the share of affiliate activity conducted in the country of origin of that ethnicity. This provides firmlevel evidence of a complementary relationship between high-skill immigration and multinational firms' activity.

Turning to other financial flows, Kugler et al. (2017) investigate the role of migration as a determinant of cross-borders financial flows such as bank loans and bonds. They introduce migration into a standard gravity model and find a positive impact of migration on financial flows. However, their empirical strategy does not focus on estimating the direct effect, which is hard to convincingly identify; rather, they focus on estimating differential effects along a number of dimensions: a skill dimension, a cultural dimension, and an asset-type dimension, with the insight that the potential for migration to foster bilateral financial flows should be stronger where information problems are more acute. They start by showing that migration has a significant positive impact on international bank loans, which is mainly driven by skilled migrants (and no effect for low skilled migrants). This result is in line with the idea that the skilled migrant diaspora is more likely to foster bilateral financial cooperation through business ties, as they are typically more integrated into the financial and labour market.

In general, the effect of migration on financial flows is magnified when countries are geographically or culturally more distant (e.g., having a common language significantly reduces the magnitude of the migration coefficient). When analysing the relationship between financial flows and migration conditioning on the lending country being a developing one, they find a larger effect for migration, coming mostly from the extensive margin. This is shown in Table 1 below, where one can see that the interaction between migration and a dummy for developing country status is significant only when the Poisson Maximum Likelihood Estimator is used but not for the OLS specification (i.e., when the estimation includes the 'zeroes' in the dependent variable). Finally, again for developing countries, they find that the effect of migration is positive and significant for assets that are more information-sensitive (i.e., for long-term bonds, while no effect is found for short-term bonds).

\subsection{Knowledge and technology diffusion}

The sociological literature (e.g., Gaillard and Gaillard, 1997; Meyer, 2001) has long recognized that the migration of scientists can facilitate the international diffusion of knowledge and technology, be it directly, through brain circulation, or indirectly through the creation and development of scientific knowledge networks. For developing countries, this is likely to affect mainly technological adoption (rather than innovation per se). Recent quantitative research in the geography of innovation has explored the role of social ties in facilitating knowledge diffusion, and in determining its spatial reach. Patent and inventor data have played a central role in quantitative contributions, with patent citations being used as a proxy for knowledge flows, and information on inventors proving a reliable means to geo-localize the invention effort (Jaffe et al., 1993; Singh and Marx, 2013; Thompson and Fox-Kean, 2005). Another way to track knowledge diffusion is to follow the evolution of the export basket of countries (Bahar et al., 2014). 
Table 1: The Effect of Migration on Loans for Developed versus Developing Countries

\begin{tabular}{lcc}
\hline Dependent variables: & $\begin{array}{c}\log (\text { Loans }) \\
(1)\end{array}$ & $\begin{array}{c}\text { Loans } \\
(2)\end{array}$ \\
\hline $\log$ Migration $_{i j}$ & $0.100^{* *}$ & $0.125^{* * *}$ \\
& $(0.047)$ & $(0.038)$ \\
$\log$ Migration $_{i j} *{\text { (Non-Developed Country })_{j}}$ & 0.058 & $0.145^{* * *}$ \\
& $(0.042)$ & $(0.038)$ \\
$\log$ Distance $_{i j}$ & $-0.744^{* * *}$ & $-0.265^{* * *}$ \\
& $(0.110)$ & $(0.050)$ \\
Obs. & 1,451 & 1,588 \\
Obs with Developed Borrowing Countries $_{\text {No. of Lending Countries }}$ & 427 & 431 \\
No. of Borrowing Countries & 17 & 17 \\
$R^{2}$ & 158 & 158 \\
Estimator & 0.86 & 0.94 \\
\hline
\end{tabular}

This table estimates the effect of migration on loans with interaction with non-developed countries. $N, L$ and $B$ denote number of observations, number of lending (investing) countries and number of borrowing (issuing) countries, respectively. Regressions are estimated by OLS and Poisson. Standard errors are clustered at the borrowing country level. All columns include country fixed effects, colonial link, language and legal origin as additional controls.

Source: Kugler, Levintal and Rapoport, 2017.

Migration, especially of scientists and inventors, can affect the stock of technological knowledge available in developing countries negatively through direct depletion coming from brain drain, quite obviously, but also positively, by creating opportunities for co-inventorship and R\&D outsourcing as well as by favouring the circulation and diffusion of knowledge. Studies using information on inventors' ethnicities (Agrawal et al., 2011; Breschi and Lissoni, 2009; Kerr, 2008, , , Kerr and Kerr, 2017) or on actual origins (Miguelez, 2017) have uncovered evidence of both. For example, Miguelez (2017) investigates the effect of diaspora inventor networks on two outcomes of interest from the perspective of developing countries: collaborative patents between home and host countries (that is, co-inventorship), and R\&D offshoring (that is, collaborations between applicants in developed countries and inventors in developing countries). The author finds a strong and robust result on the former outcome but not on the latter, suggesting that the general argument as to why highly-skilled migrants in general, and inventors in particular, can alleviate information imperfections (e.g., reduce information asymmetries, create trust among parties) and, thus, promote knowledge diffusion, holds especially for knowledge of the tacit-type. The results are shown to be not driven by India and China on the side of source countries or by the United States as receiving country. This is an important result because previous literature (e.g., Agrawal et al. 2011; Kerr 2008-) had focused on the India/China-US relationship, with the implicit assumptions that other country-pairs are less relevant. These papers, therefore, document a new channel for brain gain which complements what had already been uncovered (and detailed in the previous sections of this paper) for trade and financial flows.

Finally, Bahar and Rapoport (2018) adopt another perspective on migration and knowledge diffusion: they posit that at least for the 'tacit' part of knowledge - the one which requires direct human interaction to occur - the pattern of international knowledge diffusion should follow the pattern of international migration. Following Bahar et al. (2014), they use export growth and export 'jumps' at the product level to track the diffusion of innovation. They show that the likelihood for a country to experience such 'jumps' within a 5-year period, that is starting to export a good they have not exported before, is positively associated with the number of immigrants (emigrants) coming from (going to) countries that are experts in producing that specific type of goods. Bahar and Rapoport (2018) use international migration and trade data between over 100 countries in the 
world during 1990 to 2010 and find that the inflow of immigrants coming from countries with comparative advantage in a given product, say wine, have high explanatory power in the likelihood that the receiving country will start exporting wine in the following ten years.

The authors show that a 10 per cent increase in the immigrant stock from countries exporters of a good can explain a 2 per cent improvement in the probability of the receiving country exporting this same good, competitively and from scratch. That is, the receiving country passes from not exporting the good at all to gaining an export share above the world average (technically, having a revealed comparative advantage above one). This is suggestive of productive knowledge diffusion leading to productivity shifts at the sectorial level, because only an increase in productivity can explain a country being able to export a good to the world in a significant amount from scratch, after keeping global demand unchanged. This process appears to be strongly driven by immigrants that are considered 'skilled' (i.e., have completed enough years of education to earn at least a college degree). In fact, when comparing the ability of migrants to shape the export basket of countries, a skilled immigrant appears about ten times more 'effective' than an unskilled one (once accounting for their respective numbers).

Bahar and Rapoport (2018) further show that the results are driven mostly by instances where the receiving country is a non-OECD one (where skilled immigrants are worth about twenty times an unskilled one) nor by a simple increase in the supply of labour (the so-called Rybszynski effect), as the migration effect is found for industries both above and below average capital intensity; and that they are also not driven by a reduction of transaction costs because the effect is present for both differentiated and homogenous goods. Lastly, qualitatively similar effects are found for emigrants, as well as at the intensive margin. It is important to state that such diffusion effects are not exclusively North-South transfers; indeed, the same results hold when the sample of countrypairs is reduced to South-South country pairs. The effects are then slightly smaller in magnitude but very much in the same direction as for the full sample. Results for South-South country-pairs are shown on Table 2 below. 
Table 2: The effect of South-South migration on exports

\begin{tabular}{|c|c|c|c|c|c|}
\hline \multicolumn{6}{|c|}{ Panel A: Extensive Margin } \\
\hline & \multicolumn{3}{|c|}{ OLS } & \multicolumn{2}{|c|}{ IV } \\
\hline & $(1)$ & $(2)$ & $(3)$ & $(4)$ & (5) \\
\hline Immigrants & $\begin{array}{c}0.0030 \\
(0.001)^{* * *}\end{array}$ & & $\begin{array}{c}0.0024 \\
(0.001)^{* *}\end{array}$ & $\begin{array}{c}0.0080 \\
(0.003)^{* *}\end{array}$ & \\
\hline Emigrants & & $\begin{array}{c}0.0022 \\
(0.001)^{* * *}\end{array}$ & $\begin{array}{c}0.0011 \\
(0.001)^{*}\end{array}$ & & $\begin{array}{c}0.0079 \\
(0.003)^{* *}\end{array}$ \\
\hline Total FDI & $\begin{array}{r}-0.0001 \\
(0.000)\end{array}$ & $\begin{array}{r}-0.0001 \\
(0.000)\end{array}$ & $\begin{array}{r}-0.0001 \\
(0.000)\end{array}$ & $\begin{array}{c}-0.0003 \\
(0.000)\end{array}$ & $\begin{array}{c}-0.0003 \\
(0.000)^{*}\end{array}$ \\
\hline Total Trade & $\begin{array}{c}-0.0005 \\
(0.000)\end{array}$ & $\begin{array}{c}-0.0004 \\
(0.000)\end{array}$ & $\begin{array}{c}-0.0005 \\
(0.000)\end{array}$ & $\begin{array}{c}-0.0011 \\
(0.000)^{* *}\end{array}$ & $\begin{array}{c}-0.0009 \\
(0.000)^{* *}\end{array}$ \\
\hline Product Imports & $\begin{array}{l}-0.0008 \\
(0.000)^{*}\end{array}$ & $\begin{array}{l}-0.0008 \\
(0.000)^{*}\end{array}$ & $\begin{array}{l}-0.0008 \\
(0.000)^{*}\end{array}$ & $\begin{array}{l}-0.0009 \\
(0.000)^{*}\end{array}$ & $\begin{array}{l}-0.0008 \\
(0.000)^{*}\end{array}$ \\
\hline $\mathrm{N}$ & 83230 & 83230 & 83230 & 83230 & 83230 \\
\hline r2 & 0.15 & 0.15 & 0.15 & 0.14 & 0.14 \\
\hline KP F Stat & & & & 89.61 & 72.78 \\
\hline \multicolumn{6}{|c|}{ Panel B: Intensive Margin } \\
\hline & \multicolumn{3}{|c|}{ OLS } & \multicolumn{2}{|c|}{ IV } \\
\hline & (1) & $(2)$ & $(3)$ & (4) & (5) \\
\hline Immigrants & $\begin{array}{c}0.0058 \\
(0.001)^{* * *}\end{array}$ & & $\begin{array}{c}0.0030 \\
(0.001)^{* * *}\end{array}$ & $\begin{array}{c}0.0101 \\
(0.003)^{* * *}\end{array}$ & \\
\hline Emigrants & & $\begin{array}{c}0.0082 \\
(0.001)^{* * *}\end{array}$ & $\begin{array}{c}0.0067 \\
(0.001)^{* * *}\end{array}$ & & $\begin{array}{c}0.0107 \\
(0.003)^{* * *}\end{array}$ \\
\hline Total FDI & $\begin{array}{c}-0.0011 \\
(0.000)^{* * *}\end{array}$ & $\begin{array}{c}-0.0011 \\
(0.000)^{* * *}\end{array}$ & $\begin{array}{c}-0.0012 \\
(0.000)^{* * *}\end{array}$ & $\begin{array}{c}-0.0013 \\
(0.000)^{* * *}\end{array}$ & $\begin{array}{c}-0.0012 \\
(0.000)^{* * *}\end{array}$ \\
\hline Total Trade & $\begin{array}{c}0.0026 \\
(0.001)^{* * *}\end{array}$ & $\begin{array}{c}0.0023 \\
(0.001)^{* * *}\end{array}$ & $\begin{array}{c}0.0018 \\
(0.001)^{* * *}\end{array}$ & $\begin{array}{l}0.0016 \\
(0.001)\end{array}$ & $\begin{array}{c}0.0017 \\
(0.001)^{*}\end{array}$ \\
\hline Baseline Exports & $\begin{array}{c}-0.0453 \\
(0.002)^{* * *}\end{array}$ & $\begin{array}{c}-0.0456 \\
(0.002)^{* * *}\end{array}$ & $\begin{array}{c}-0.0459 \\
(0.002)^{* * *}\end{array}$ & $\begin{array}{c}-0.0460 \\
(0.002)^{* * *}\end{array}$ & $\begin{array}{c}-0.0460 \\
(0.002)^{* * *}\end{array}$ \\
\hline Product Imports & $\begin{array}{c}0.0038 \\
(0.001)^{* * *}\end{array}$ & $\begin{array}{c}0.0039 \\
(0.001)^{* * *}\end{array}$ & $\begin{array}{c}0.0039 \\
(0.001)^{* * *}\end{array}$ & $\begin{array}{c}0.0039 \\
(0.001)^{* * *}\end{array}$ & $\begin{array}{c}0.0040 \\
(0.001)^{* * *}\end{array}$ \\
\hline Previous Exports Growth & $\begin{array}{c}-0.0045 \\
(0.001)^{* * *}\end{array}$ & $\begin{array}{c}-0.0045 \\
(0.001)^{* * *}\end{array}$ & $\begin{array}{c}-0.0044 \\
(0.001)^{* * *}\end{array}$ & $\begin{array}{c}-0.0043 \\
(0.001)^{* * *}\end{array}$ & $\begin{array}{c}-0.0045 \\
(0.001)^{* * *}\end{array}$ \\
\hline Zero Exports in t-1 & $\begin{array}{c}-0.0884 \\
(0.007)^{* * *}\end{array}$ & $\begin{array}{c}-0.0879 \\
(0.007)^{* * *}\end{array}$ & $\begin{array}{c}-0.0881 \\
(0.007)^{* * *}\end{array}$ & $\begin{array}{c}-0.0886 \\
(0.007)^{* * *}\end{array}$ & $\begin{array}{c}-0.0879 \\
(0.007)^{* * *}\end{array}$ \\
\hline $\mathrm{N}$ & 95656 & 95656 & 95656 & 95656 & 95656 \\
\hline r2 & 0.35 & 0.35 & 0.35 & 0.35 & 0.35 \\
\hline KP F Stat & & & & 58.21 & 78.93 \\
\hline
\end{tabular}

Standard errors clustered at the partner country level reported in parenthesis.

${ }^{*} p<0.10, \cdots p<0.05, \cdots p<0.01$

Source: Bahar and Rapoport, 2018 (forthcoming). 
Bahar et al. (2017) exploit a natural experiment on Yugoslavian refugees in Germany to analyse how return migration contributes to technology diffusion across countries. In particular, the authors estimate changes in exports to the rest of the world as explained by return migration of workers employed in that same sector in Germany. Following the Balkan wars during the early 1990s, about seven hundred thousand Yugoslavians migrated to Germany and were, given some limitations, allowed to participate in the local labour force. Most of the Yugoslavian migrants in the first half of the 1990s were given a temporary protection status. After the Dayton peace agreement was signed in 1995, the protection status and work permit of the temporary migrants were revoked and subsequently they were forced to leave the country. By 2000, about two thirds of migrants with the temporary status had left. A large proportion of them, in fact, returned to the countries of former Yugoslavia.

The authors rely on data from the German Institute for Employment Research (IAB) to compute the number of Yugoslavian migrants working in a particular 4-digit industry before and after the Balkan refugee crisis. They link this information to standard disaggregated international trade data, to employ a difference-in-difference methodology and estimate changes in export values from Yugoslavian countries to the rest of the world caused by return migration of Yugoslavian workers in Germany. In order to address concerns of endogeneity due to self-selection of workers into industries with potential pre-existing growth trends in Yugoslavia, they instrument the actual number of returning workers per industry with the expected number given a spatial dispersal policy that exogenously allocated asylum seekers across the different regions of Germany upon their arrival.

Bahar et al. (2017) show that products of industries that experienced more return migration, as measured by 'losses' of workers in the corresponding German industry between 1995 and 2000, also saw an increase in exports to the rest of the world (i.e., excluding Germany, to rule out results potentially driven by the network effects discussed in Section 2.1 above). The point estimate shows that a one per cent increase in return migration leads to an increase of 0.13 to 0.33 per cent in exports between the pre-war period 1985-90 and the post-war period of 2005-10 (see Table 3). This result holds when exports to Germany are excluded. The elasticity becomes stronger over time, e.g. the effect picks up a few years after the refugees' return. The authors argue that these results cannot be explained by an existing previous trend on exports, nor by FDI flows from Germany to Yugoslavian countries during those same years. In a second step, the authors expand their methodology to a multi-country and multi-period setting. In this setting they estimate changes in exports for over 100 countries and close to 800 products as explained by changes in stocks of migrant workers in Germany in two periods: 1990 to 2000 and 2000 to 2010. The authors estimate elasticities that range from 0.09 to 0.11 , which are remarkably similar to the ones estimated using the Yugoslavian natural experiment. 
Table 3: Difference in Differences Estimation

Exports of former Yugoslavian Republics, 1985-90 and 2005-10

\begin{tabular}{|c|c|c|c|c|c|c|}
\hline \multicolumn{7}{|c|}{ Dependent variable: exports $p, t$} \\
\hline & \multicolumn{3}{|c|}{ OLS } & \multicolumn{3}{|c|}{$2 \mathrm{SLS}$} \\
\hline & Inexp & Inexpplus1 & asinhexp & Inexp & Inexpplus1 & asinhexp \\
\hline treat $2000 \times$ after 2005 & $\begin{array}{c}0.1281 \\
(0.040) * * *\end{array}$ & $\begin{array}{c}0.2251 \\
(0.063)^{* * *}\end{array}$ & $\begin{array}{c}0.2291 \\
(0.065)^{* * *}\end{array}$ & $\begin{array}{c}0.1885 \\
(0.049)^{* * *}\end{array}$ & $\begin{array}{c}0.3252 \\
(0.084) * * *\end{array}$ & $\begin{array}{c}0.3311 \\
(0.086)^{* * *}\end{array}$ \\
\hline Infdi & $\begin{array}{c}-0.1696 \\
(0.069)^{* *}\end{array}$ & $\begin{array}{c}-0.2600 \\
(0.121)^{* *}\end{array}$ & $\begin{array}{c}-0.2641 \\
(0.125)^{* *}\end{array}$ & $\begin{array}{c}-0.1734 \\
(0.070)^{* *}\end{array}$ & $\begin{array}{c}-0.2663 \\
(0.122)^{* *}\end{array}$ & $\begin{array}{c}-0.2704 \\
(0.126)^{* *}\end{array}$ \\
\hline N & 1520 & 1572 & 1572 & 1520 & 1572 & 1572 \\
\hline r2 & 0.86 & 0.80 & 0.80 & 0.86 & 0.80 & 0.80 \\
\hline KP F Stat & & & & 2841.59 & 2985.62 & 2985.62 \\
\hline
\end{tabular}

This table shows result of the estimation using different monotonic transformations for exports,$t$ in each column. The estimation aggregated exports by product in years 1985-1990 and 2005-2010. All columns include product fixed effects and year fixed effects. Standard errors clustered at the product level presented in parenthesis.

${ }^{*} p<0.10,{ }^{* *} p<0.05,{ }^{* * *} p<0.01$

Source: Bahar et al.,2017.

\section{Cultural integration: social remittances}

The concept of social remittances was initially introduced by sociologists to designate migrants' transfers of behavioural and cultural norms to their communities of origin (Levitt, 1998). It has since inspired a large body of research in demography, political science and economics. First, this section will give an overview of the evidence on political remittances and so-called Malthusian remittances (remittance of fertility norms) on a micro-level. In the second part, I will turn to a global analysis of international migration and cultural convergence both from a theoretical and empirical perspective.

\subsection{Political remittances}

Emigration can affect the political and institutional evolution of developing countries in many ways, starting from the migrants' self-selection on political grounds (Hirshman's 'exit' effect) and ending with diasporas' involvement in domestic politics. Another channel through which migrants can affect home country institutions is through 'political remittances', that is, the transfer of political norms and attitudes (regarding, for example, democracy and corruption) from host to home countries. The term 'political remittances' is the transposition to the political realm of the concept of social remittances (Levitt, 1998). The general idea borrowed from the literature on social remittances is that while abroad, migrants absorb new information and are exposed to new political institutions, attitudes and practices that can first transform their own political views (e.g., Barr and Serra, 2010; Cain et al., 1991; Luttmer and Singhal, 2011) and then spill over to their home communities through direct and indirect contacts with relatives, friends and other members of their home-based social networks (Levitt, 1998; Shain, 1999). The notion has inspired a large body of research in demography, political science and economics. There is a rich qualitative and descriptive socio-political literature documenting the phenomenon, however the quantitative evidence is both scarce and weak. Still, this socio-political literature has a few important insights that can guide empirical research. First, 'destination matters': if migrants are to transfer the political attitudes and institutional norms of their host countries, then, depending on where they are, they will remit different norms and values. And second, 'timing matters': it takes time for individual preferences to evolve, and even more time for these preferences to be transferred and digested by 
recipients in the home countries. The recent economic literature includes both cross-country comparisons and a number of country case-studies. They converge in suggesting that emigration entails a significant democratic dividend when emigration is directed toward democratic countries (destination matters); careful country-case studies moreover suggest that a good deal of the effect can be attributed to the transfer of political attitudes and preferences that, after some time (time matters), also translate into political outcomes (e.g., elections) at home.

\section{Cross-country evidence}

In an influential paper, Spilimbergo (2009) used cross-country comparisons in a panel setting to show that foreign-trained individuals promote democracy in their home countries, but only if foreign education was acquired in a democratic destination. While he does not identify the mechanisms at work, he suggests a number of possible channels (e.g., access to foreign media, acquisition of norms and values while abroad that diffuse at home upon return, willingness to preserve the quality of one's network abroad, etc.) that can be generalized to other migration experiences as well. This is precisely what Docquier et al. (2016) are doing: they estimate the effect of emigration on home-country institutions for all migrants, not just foreign students, and find that openness to migration, as measured by the total emigration rate, contributes to improved institutional quality.

Both papers investigate the overall impact of emigration on home-country institutions. This overall effect is composed of the direct (or exit) effect of emigration, that is, the fact that emigrants may be positively self-selected in terms of education and preferences for democracy (which should translate into a negative impact on democracy at home) and indirect effects such as political remittances or the role of diasporas. The two papers are similar in terms of methodology - they use dynamic panel regressions and similar dependent variables (i.e., indices of democracy such as the Polity IV index or indices of Civil Liberties and Political Rights published yearly by the Freedom House). They, then, try to confront the obvious endogeneity issue arising from the fact that bad political institutions can generate either more (due to stronger push factors) or less (due to repressive policies) emigration, creating a spurious correlation between the size of emigration and the quality of institutions. Beyond their focus on different emigrant populations (foreign students $v$. all migrants), the two papers differ in many other respects.

First, Spilimbergo (2009) uses data on the number of people with foreign training living either abroad or at home, making it impossible to know whether the effect uncovered is due to those staying abroad or to those who returned. In terms of analogy with monetary remittances, this is similar to trying to make a distinction between remittances per se (that is, money sent by migrants residing abroad) and repatriated savings upon return. Docquier et al. (2016), in contrast, use an emigration variable that consists of the lagged accumulated stock of individuals (aged 25+) born in the home country and living abroad, and which would seem to exclude return migration as the main channel for the effect.

Second, Spilimbergo's (2009) main result is the identification of destination-specific effects, with a positive coefficient obtained only when foreign education comes from a democratic country. In Docquier et al. (2016), the panel specifications use immigration data to OECD destinations only, and given that these destination countries are very homogenous in terms of democratic performance this means that it is impossible to test for the effect of emigration to democratic v. non-democratic countries. However, in their cross-sectional specifications, they are able to use immigration data for the full sample of world countries and to confirm that all of the positive effect of emigration on democracy is due to emigration to the democratic countries. 
Finally and most importantly, the main robust result in Spilimbergo (2009) is the positive coefficient of the 'democratic norm at destination' variable; this is a weighted average of democratic scores at destination, which captures whether emigration is directed toward more or less democratic countries. The interpretation is that what matters for democratization is whether students study in a democratic country, not how many of them do so. For this, one must interact this 'democratic norm at destination' variable with the number of foreign students; however, in all of Spilimbergo's specifications but one, this interaction term is not significant. In contrast, Docquier et al.'s (2016) main results are for the volume of migration, suggesting that whether a country has a one or twenty per cent emigration rate makes a difference, not just whether its emigration is directed toward destinations with high or low democracy scores.

In terms of estimation methods, Spilimbergo (2009) relies on SGMM estimation with internal instruments while Docquier et al. (2016) use a large set of different specifications: cross-sectional analysis (OLS and 2SLS), and panel analysis (OLS, OLS with fixed-effects, 2SLS, and SGMM) and for different indices of institutional quality. In all of these models, emigration consistently turns positive and very significant. The long-run effect of emigration estimated in 2SLS cross-sectional and panel regressions stands between 1.2 and 1.5, depending on the specification. These results are shown to be also robust across sub-samples (excluding oil countries, Sub-Saharan African countries, or former Communist countries). Interestingly, there is no apparent additional effect for skilled emigration.

Lodigiani and Salomone (2016) analyse another, more specific dimension of democracy: the role of women in politics as measured by the share of female members of the National Parliament. In the spirit of the political remittances literature above, they hypothesize that international migration to countries where the share of women in the parliament is higher is likely to increase female parliamentary share in the source country. The authors' main variable of interest is the index of female parliamentary share, which is constructed as the difference in female parliamentary participation between host and home countries, weighted by the share of migrants to that host country on the overall population (as in Spilimbergo, 2009). They include country of origin and time-fixed effects, control for important economic and socio-political covariates such as female education, the type of electoral system, or general wealth in the society, and address reverse causality using a gravity-based model to predict bilateral migration stocks (as in Alesina et al., 2016 or Docquier et al., 2016; Ortega and Peri, 2014). The paper uses information on the gender composition of national parliaments between 1960 and 2003 and bilateral migration data between 1960 and 2000, which they combine with other databases to construct a panel data set of 170 countries over five decades. Their results suggest that international migration to countries with higher female parliamentary participation have a positive and significant effect on the female parliamentary share at origin (by about 1.7 percentage points for a 10-percentage point increase in migration). This holds under all specifications and is robust to excluding certain subsamples (such as post-communist, Muslim, and Sub-Saharan African countries).

Overall, this cross-country literature demonstrates a total positive impact of emigration on homecountry institutions. While the generality of the results is important in its own right, the main limitation of these studies is that they cannot disentangle the relative contributions of the potentially many channels involved. In particular, they cannot isolate the diffusion of democratic norms (namely, political remittances) from other candidate explanations. For this, a more detailed analysis is required, at a more disaggregated level.

\section{Country case-studies}

Country case-studies generally use administrative or individual data (or both). The fact that they focus on smaller entities for which richer information is available allows for a deeper exploration 
of alternative channels. The micro literature includes a number of country case-studies. For example, Batista and Vincente (2011) document that households in Cape Verde with a migrant abroad, particularly those with a migrant to the US, have a higher demand for political accountability. Pérez-Armendáriz and Crow (2010) find that individuals in Mexico in households with a migrant in the US or Canada are more likely to vote. Chauvet and Mercier (2014) also focus on voter turnout and report a similar result for Mali. Pfutze (2012) studies Mexico's local elections of 2000 and shows that municipalities with many migrants in the US are more likely to vote for opposition parties. These papers are all interesting and carefully executed, however they all suffer from one or both of the two following issues: they study a country with a single foreign destination (as is the case for Mexico), making it impossible to analyse destination-specific effects; or they concern countries with very long migration traditions, making it impossible to control for premigration political preferences and outcomes.

These issues are addressed in Barsbai et al. (2017) for Moldova. The authors take advantage of the natural experiment constituted by the Russian crisis of 1998, which sparked emigration out of Moldova, a country with previously no ties to the West and very little emigration even to other former Soviet Union Republics, as it was highly specialized in agriculture and dependent on agricultural exports to Russia. This lack of export diversification is precisely why Moldova was harder hit by the crisis (much more than Russia). In the few years after the crisis more than 20 per cent of the workforce emigrated: two thirds went to Russia ('East') and one third to the European Union (West). Interestingly, while certain Moldovan communities had predominantly westward emigration during that period others had predominantly eastward emigration: but these communities behave in similar ways politically, that is, they had similar electoral behaviour. In particular, the share of votes for the Communist Party, which was in power between 2001 and 2009, were very close in the elections of 1998, 2001, and 2005, and it is only in the 2009 and 2010 elections that the two types of communities (from an emigration viewpoint) started to diverge politically (see Figure 1).

Barsbai et al. (2017) explore the reasons behind this divergence and show that it can be 'causally' explained by the differential effects of eastward v. westward emigration. They show that emigration to Western Europe in the late 1990s and the early 2000s substantially affected electoral outcomes in the Moldovan national elections of 2009 and 2010, increasing the share of votes for democratic parties and reducing that of the then ruling Communist Party (and conversely for emigration to Russia and other Eastern European destinations), strongly enough to overturn the election results (which were just won by a coalition of democratic, pro-European parties). They also provide suggestive evidence that the observed effects likely work through the diffusion of information and of norms from abroad. The authors find that a one percentage point increase in the community prevalence of westward migration reduces the Communist vote share by about 0.6 percentage points (see Table 4). Additionally, they find that electoral divergence across communities only sets in with a time-lag, supporting their hypothesis about the diffusion of values channel. This is further supported by the fact that the effect on electoral outcomes is strongest for communities with a larger share of low-educated residents and with a higher share of people who grew up under the Soviet regime), because these are communities where the transmission of values, presumably, has the largest informational value. 
Figure 1: Communist votes, number of emigrants in stocks, and volume of calls from abroad to Moldova, 19982009

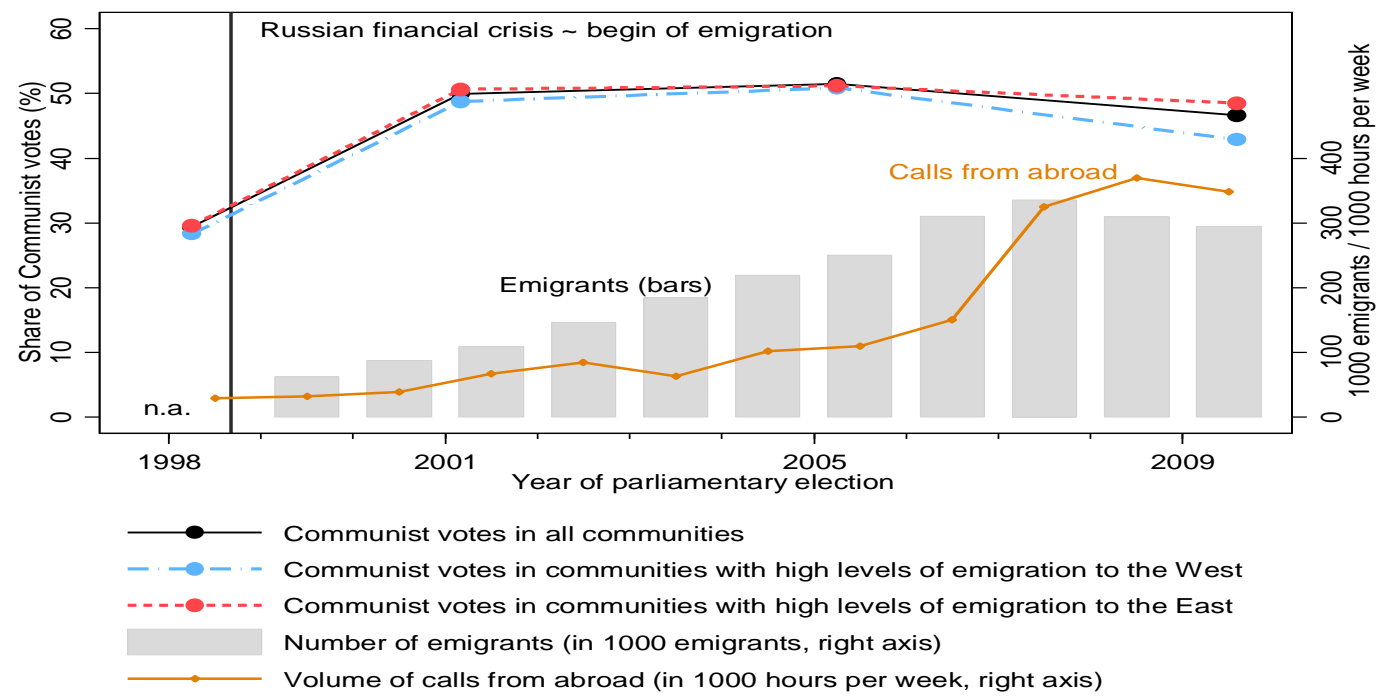

Source: Figure 1 in Barsbai et al., 2017.

Table 4: East/West Migration and General Election Results in Moldova, July 2009

\begin{tabular}{|c|c|c|c|c|c|c|c|}
\hline & \multicolumn{3}{|c|}{$\begin{array}{l}\text { Share of votes for the } \\
\text { Communist Party (\%) }\end{array}$} & \multicolumn{4}{|c|}{$\begin{array}{c}\text { Share of votes for } \\
\text { opposition parties (\%) }\end{array}$} \\
\hline & $\begin{array}{l}\text { Basic } \\
\text { controls }\end{array}$ & $\begin{array}{l}\text { Plus pre- } \\
\text { migration } \\
\text { election } \\
\text { results }\end{array}$ & $\begin{array}{l}\text { Plus night- } \\
\text { time light } \\
\text { (full model) }\end{array}$ & $\begin{array}{c}\text { Liberal } \\
\text { Democratic } \\
\text { Party }\end{array}$ & $\begin{array}{l}\text { Liberal } \\
\text { Party }\end{array}$ & $\begin{array}{l}\text { Demo- } \\
\text { cratic } \\
\text { Party }\end{array}$ & $\begin{array}{l}\text { Party } \\
\text { Alliance } \\
\text { Our } \\
\text { Moldova }\end{array}$ \\
\hline & $(1)$ & $(2)$ & (3) & $(4)$ & $(5)$ & $(6)$ & $(7)$ \\
\hline $\begin{array}{l}\text { Prevalence of emigration } \\
\text { to the West }(\%)\end{array}$ & $\begin{array}{c}-0.70^{\star \star *} \\
(0.20)\end{array}$ & $\begin{array}{l}-0.63^{\star \star \star} \\
(0.18)\end{array}$ & $\begin{array}{c}-0.63^{\star \star *} \\
(0.18)\end{array}$ & $\begin{array}{l}0.40 * \star \star \\
(0.13)\end{array}$ & $\begin{array}{l}0.24^{\star *} \\
(0.11)\end{array}$ & $\begin{array}{c}0.08 \\
(0.12)\end{array}$ & $\begin{array}{l}-0.16 \\
(0.15)\end{array}$ \\
\hline $\begin{array}{l}\text { Prevalence of emigration } \\
\text { to the East }(\%)\end{array}$ & $\begin{array}{l}0.44^{\star *} \\
(0.17)\end{array}$ & $\begin{array}{l}0.39 * * \\
(0.16)\end{array}$ & $\begin{array}{l}0.39 * * \\
(0.16)\end{array}$ & $\begin{array}{l}-0.07 \\
(0.09)\end{array}$ & $\begin{array}{l}-0.17^{\star \star} \\
(0.07)\end{array}$ & $\begin{array}{l}-0.07 \\
(0.08)\end{array}$ & $\begin{array}{l}-0.01 \\
(0.11)\end{array}$ \\
\hline Basic controls & yes & Yes & yes & yes & yes & yes & yes \\
\hline $\begin{array}{l}\text { Pre-migration election } \\
\text { results }\end{array}$ & - & Yes & yes & yes & yes & yes & yes \\
\hline Night-time light & - & - & yes & yes & yes & yes & yes \\
\hline District fixed effects & yes & yes & yes & yes & yes & yes & yes \\
\hline Number of observations & 848 & 848 & 848 & 848 & 848 & 848 & 848 \\
\hline $\mathrm{R}^{2}$ & 0.78 & 0.82 & 0.82 & 0.56 & 0.66 & 0.42 & 0.37 \\
\hline
\end{tabular}

Notes: The table reports OLS estimates for 848 Moldovan communities. The dependent variables are the vote shares of different parties in the July 2009 parliamentary election at the community level (in per cent). Table A3 in the appendix shows the full regression results. Standard errors clustered at the district level in parentheses. ${ }^{\star \star \star}$ denotes statistical significance at the 1 per cent level, ${ }^{* *}$ at the 5 per cent level, and * at the 10 per cent level.

Source: Barsbai et al., 2017.

\subsection{Malthusian remittances}

Do the effects uncovered for political remittances extend to fertility? Actually, we should ask the question the other way around and acknowledge the seniority of demography over political economy in the context of social remittances. It all started with the observation and comparative analysis of Philippe Fargues (2007) regarding the demographic transition in Middle Eastern and 
Northern African (MENA) countries. Noting that emigration is associated with lower birthrates in MENA countries whose main destination is the West while it is associated with higher birthrates where emigration is going eastward (i.e., to the Gulf countries), Fargues (2007) conjectured that this can be explained by destination-specific effects. For example, most Moroccan emigrants live in Western Europe and Northern America, which are low fertility regions, while most Egyptian emigrants live in highly traditional and fertile Persian Gulf countries. The Fargues conjecture has been taken seriously not just by demographers but also by economists who tested it econometrically in cross-country comparisons (Beine et al., 2013) as well as in various contemporary (Bertoli and Marchetta, 2015, for Egypt) and historical (Daudin et al., 2016, for internal migrations in 19th century France) settings.

Fargues (2007) argues that international migration has helped containing the 'demographic explosion', namely the risk of world overpopulation, by transferring norms and values on family structure from migrants' host (and mostly developed, low-birth) countries to their home communities. He suggests that during the period of demographic transition, emigrants acted as agents of cultural diffusion of norms of low fertility and small family size. He conjectures that emigration will modify the course of the demographic transition of emigrants' origin countries and that such impact will depend on the destination of migration. To substantiate his argument, Fargues (2007) uses macro-level descriptive statistics on migration from the Middle East and North Africa to the West or the Gulf States. The demographic transition is expected to accelerate where emigrants are heading West (and North) and to be contained if not reversed where emigrants are heading East, that is, towards the Gulf region.

Daudin et al. (2016) explore the role of migration and fertility norms for intra-national migration in France. In fact, France experienced the demographic transition before richer and more educated countries. The authors' analysis offers a novel explanation for this puzzle that emphasizes the diffusion of culture and information through internal migration. It tests how migration affected fertility by building a decennial bilateral migration matrix between French regions for 1861-1911.

Their results suggest that fertility declined more in areas that (i) had more emigration and (ii) whose migrants migrated towards low-fertility regions, especially Paris. These results are robust to accounting for the potential confounding effects of factors such as declining child mortality, increased life expectancy, rising education levels, industrialization and religiosity. Daudin et al.'s interpretation is that emigrants who moved from high- to low-fertility areas transmitted cultural and economic information about fertility norms and the cost of raising children in the regions where they had settled to the inhabitants of the regions where they came from. This information might have been then taken into account by actual and would-be emigrants, thus explaining why we find that departments with a larger share of emigrants experienced a larger drop in fertility. This interpretation is supported by the fact that emigration to Paris, which accounted for 26.33 per cent of the total number of French internal emigrants between 1861 and 1911, explains half of the national decline in fertility (which is in line with the economic, political and cultural importance of Paris within France). The results still hold when accounting for child mortality and other potential factors of information diffusion and cultural change, such as newspapers, the age at marriage or the number of children born out of wedlock.

\subsection{Other aspects of societal change}

Entrepreneurial and managerial skills

Marchetta (2012) draws on a panel survey conducted in Egypt in 1998 and 2006 to analyse the relationship between the survival of an entrepreneurial activity and the migration status of the entrepreneur. She employs a bivariate probit estimation and applies the same instrumental 
approach mentioned above. The analysis reveals that entrepreneurial activities by Egyptian returnees enjoy a probability of survival that is 35 percentage points higher than the corresponding estimated probability for stayers, even after controlling for a possible positive selection of migrants. These results suggest that entrepreneurial skills and management capacities are applied to labour market activities of returning migrants in their home countries, supporting the social remittance hypothesis.

\section{Religiosity and religious tolerance: evidence from the Haij}

Clingingsmith et al. (2009) analyse the social consequences of the Muslim pilgrimage to Mecca, known as the Hajj. They find that the on average 40-day pilgrimage leads to a persistent change towards more religious tolerance in Pakistani pilgrims' attitudes, beliefs, and practices at home. The authors make use of a lottery set up by the Pakistan government to randomly allocate Hajj visas to 90,000 individuals, among a total of 134,948 applicants. The authors argue that comparing winners and losers of the lottery is an ex-ante remedy to the potential self-selection into Hajj pilgrims and give evidence that the lottery outcome is uncorrelated with any observable characteristics of applicants. The results suggest that returnees from Hajj exhibit more rigorously Islamic practices (such as prayer or fasting) whereas they participate less in localized practices and beliefs (such as the use of amulets and dowry); Hajjis express more tolerance, have more favorable attitude towards women and are more likely to believe in equality and harmony among Muslims but also among ethnic groups. The authors discuss different channels which could explain these results and conclude that the exposure and the interactions to other Muslims sharing the same faith but having other attitudes, preferences and beliefs may alter their thought frames.

\section{Gender roles and women's empowerment}

In their paper 'Migration-induced Transfers of Norms. The case of Female Political Empowerment' Lodigiani and Salomone (2015) investigate the causal link between international migration and the political empowerment of women, measured by the change in the share of female members of the National Parliament. The authors hypothesize that migrants abroad undergo a 'political socialization', that is migrants adopt values and norms but also political practices of their host countries and will eventually diffuse these experiences to their communities in the country of origin. Consequently, international migration to countries where the share of women in the parliament is higher is likely to increase female parliamentary participation in the source country.

The authors show that there is indeed a positive and significant link between the lagged index of female parliamentary share and the change in female parliamentary seats. In the short run, total international migration to countries with higher female parliamentary participation increases the female parliamentary shares in countries of origin by about 1.7 percentage points. However, Lodigiani and Salomone also constitute that the construction of their 'norms' variable implies that the origin country only takes advantage of the political environment at destination if the female political conditions are better at destination than at origin. Lodigiani and Salomone address an important dimension of international migration and show how political socialization of migrants will eventually lead to a convergence in political norms between host and home country. This convergence typically favours female parliamentary participation which implies that international migration has the power to foster gender equality. The authors provide evidence on a macro scale for the existence of 'informational channels' that are able to transfer foreign values, create favourable opportunities, reshape attitudes and create new norms and thus support the social remittances hypothesis. 


\subsection{International migration and cultural convergence}

While the micro-studies above highlight specific cultural traits, such as political preferences or fertility, this section will extend the notion of cultural convergence to a full set of cultural dimensions (such as religiosity, social capital, work-life balance etc.). This analysis will also take a macro perspective and give an aggregate picture of the relationship between migration and cultural similarity. As I have shown in the previous sections, the movement of people (rather than goods or investments) is a major driver of cultural proximity between countries, as preferences, attitudes and norms are embedded in individuals that carry those ideas with them and migrants can also diffuse back the social and cultural norms they learn in their new environment through interactions with home-based social networks.

Rapoport et al. (2017) investigate the role of international migration on the convergence or divergence of attitudes and values between countries. In particular, the authors focus on the question of whether bilateral migration makes sending and receiving countries more similar or dissimilar in terms of political and economic attitudes, trust, attitudes to risk, and religiosity. Their analysis consists of two parts: i) a theoretical model of migration-based cultural change, and ii) an empirical analysis for a panel of countries between 1981 and 2014, combining data from rounds of the Word Value Survey and the World Bank's bilateral migration data set.

Rapoport et al.'s theoretical framework on migration-based cultural convergence conceptualizes several phenomena that we intuitively associate with migration. First, if migrants self-select themselves on cultural grounds (e.g., are more liberal, prefer small families) and move to a country with norms and values more similar to their own, they will leave behind a population with more dissimilar preferences on average (the exit-effect) than at destination. Taking this thought experiment to the extreme would imply that with migrants choosing destinations solely based on culture, we would observe a global cultural sorting where countries are very homogeneous internally but culturally very different one from the other, causing cultural divergence across countries. The model acknowledges that individuals choose to emigrate for economic as well as cultural reasons. The balance between those two incentives can vary and ultimately determines how prevalent the exit-effect will be. Second, the idea of a cultural melting pot, where immigrants bring their norms and values with them and diffuse them within the host population is another popular concept relating to migration and cultural formation. Home and host countries become more similar culturally by mere social mixing (or cultural mixing). Additionally, over time migrants may adopt values of their host community, making the host population more homogeneous through assimilation but rendering host and home countries more distant culturally. Lastly, migrants rarely cut their ties completely and stay in touch with their origin communities either through family and other types of social networks or more directly by returning temporarily or for good. In doing so, they transmit values and norms through so called social remittances, thereby contributing a vital part in the cultural formation in their home countries.

The paper proposes a unified theoretical framework to disentangle these four effects. In this framework, migration can either lead to cultural convergence or divergence and consists of two major parts i) a compositional model (CM) and ii) a transmission model of migration-based cultural change (TM). The first model deals with the incentives that lie behind the individual migration decision. The decision to migrate is motivated by both cultural homophily and a universal quest to improve one's material situation. Individuals weigh between economic and cultural costs/gains from migration. If the cultural motive dominates, the pool of emigrants will be more selected, e.g. those who emigrate will resemble the population at destination more than the population at home. Consequently, from a purely compositional standpoint, this would predict cultural divergence between home and host populations. In the second part of the model we acknowledge cultural interactions between immigrants and the host population as well as between emigrants and their 
home population and consider cultural dynamics, using the Bisin and Verdier (2000) framework, where culture is transmitted either vertically (through the parents) or horizontally (through a role model). If we assume that migrants continue to be role models for the population which remained at home, as anecdotal and empirical evidence suggests, then culture diffuses across borders and home and host populations may converge culturally.

The analysis complements the unified theoretical approach with a rich empirical analysis, focusing on the dynamic aspect of culture. The authors construct a global data set for time-varying bilateral cultural distance measures, making sure that compositional effects (i.e., changes in the number or types of questions used in the World Value Survey) do not influence the outcomes. Additionally, the analysis incorporates several different statistical distance measures. These distance measures (most prominent measures include the Euclidean distance and the Herfindahl index) capture different aspects of similarity, some of them highlighting the overlap of responses between respondents from different countries, others looking at how similar the most dissimilar people between two countries are (comparing the two extremes).

The empirical analysis tests the conditions under which the model predicts cultural convergence or divergence for over six thousand country pairs between 1981 and 2014. The authors can only detect an aggregate effect (reduced form), showing which of the two forces (convergence or divergence) dominates. Using a gravity model of cultural convergence with country pair and timefixed effects, the authors show that bilateral migration leads to cultural convergence and that the diffusion effect dominates. The authors then conduct different analyses that either support the compositional model (CM) or the transmission model (TM) and find evidence for the channels proposed in the TM. The mechanisms themselves are then tested in a heterogeneity analysis, differentiating between country pairs with high economic versus cultural incentives for migration or identifying respondents in the WVS data set that are immigrants (this information is available for 2 waves). Derived from the TM model, the authors expect convergence to be higher for initially distant country-pairs and for country-pairs with high levels of interaction between the diaspora and the home community, which is confirmed in the data. As shown in Table 5 and consistent with the model, the effect mainly stems from South-North migration, where economic reasons for emigration are typically higher and where initial cultural distance is bigger. Incorporating all the effects in the unified model and empirical analysis, the paper absorbs a major concern of migration economists, which is to single out the selection of migrants (and the underlying endogeneity of migration) when analysing the effect of migration on economic or political outcomes in sending or receiving countries. 
Table 5: Bilateral Migration and Cultural Convergence by Development Status

\begin{tabular}{l|ccc|ccc|ccc} 
& \multicolumn{3}{|c}{ North-North } & \multicolumn{3}{c}{ South-North } \\
\hline & $\begin{array}{c}\text { Euclidean } \\
(1)\end{array}$ & $\begin{array}{c}\text { Herfindahl } \\
(2)\end{array}$ & $\begin{array}{c}\text { Canberra } \\
(3)\end{array}$ & $\begin{array}{c}\text { Euclidean } \\
(4)\end{array}$ & $\begin{array}{c}\text { Herfindahl } \\
(5)\end{array}$ & $\begin{array}{c}\text { Canberra } \\
(6)\end{array}$ & $\begin{array}{c}\text { Euclidean } \\
(7)\end{array}$ & $\begin{array}{c}\text { Herfindahl } \\
(8)\end{array}$ & $\begin{array}{c}\text { Canberra } \\
(9)\end{array}$ \\
\hline \multirow{4}{*}{ Migration } & & & & & & & & & \\
& -0.00334 & $-0.0564^{*}$ & $-0.209^{* * *}$ & $0.0541^{* * *}$ & $0.0367^{* * *}$ & $0.0616^{* * *}$ & 0.0111 & 0.0121 & 0.0129 \\
Trade & $(0.0384)$ & $(0.0316)$ & $(0.0595)$ & $(0.0151)$ & $(0.0124)$ & $(0.0192)$ & $(0.0146)$ & $(0.0112)$ & $(0.0162)$ \\
& 0.0484 & 0.00482 & -0.0660 & -0.0120 & -0.0199 & -0.0394 & $-0.0392^{*}$ & -0.0220 & 0.00725 \\
Constant & $(0.0971)$ & $(0.0798)$ & $(0.150)$ & $(0.0256)$ & $(0.0210)$ & $(0.0326)$ & $(0.0228)$ & $(0.0175)$ & $(0.0252)$ \\
& -0.360 & 1.412 & 4.312 & -0.540 & -0.145 & 0.0573 & $0.909^{* *}$ & 0.324 & -0.0141 \\
& $(2.159)$ & $(1.774)$ & $(3.345)$ & $(0.521)$ & $(0.428)$ & $(0.662)$ & $(0.448)$ & $(0.344)$ & $(0.496)$ \\
Observations & 702 & 702 & 702 & 3,108 & 3,108 & 3,108 & 3,173 & 3,173 & 3,173 \\
R-squared & 0.953 & 0.991 & 0.944 & 0.983 & 0.982 & 0.966 & 0.958 & 0.981 & 0.960 \\
\hline
\end{tabular}

Standard errors in parentheses, ${ }^{* * *} \mathrm{p}<0.01,{ }^{*} \mathrm{p}<0.05,{ }^{*} \mathrm{p}<0.1$, OLS regression with full set of fixed effects (bilateral FE, destination-year FE, origin-year FE). Sample split into 3 categories: North-North for bilateral migration between OECD countries (members in 2014), South-South

Source: Rapoport, Sardoschau and Silve, 2017.

\section{Conclusion}

The 'migration' component of globalization has long been seen either as a safety net (allowing to export one's demographic surplus and receive insurance income from remittances) or as a threat (in the case of brain drain) for developing countries. Recent research suggests that migration must also be seen as a way for emerging and developing countries to integrate further into the world economy. In particular, in the light of recent empirical evidence, the role of migration and diaspora networks must be considered as a potentially significant generator of brain gain. This paper reviews a growing and important series of studies demonstrating time and again the trade-creating effect of migration not just for goods but also for financial (especially FDI) and knowledge flows. In fact, migrants contribute to the integration of their home countries into the world market as they encourage cross-border investments and trade in goods through the preference channel, primarily affecting imports in differentiated goods, and through the information channel, affecting both imports and exports, because immigrants can provide expertise knowledge in the socio-economic and legal conditions in their countries of origin and thus mitigate information frictions to trade. The evidence further confirms the comparative advantage of skilled migrants in this respect, particularly through the informational channel and the diffusion of knowledge.

Moreover, a large part of the literature on social remittances agrees that migrants-as they are exposed to new values and norms abroad-absorb new information and are able to transfer some of this information to their home communities. We see this both on a national and global scale. This has strong policy implications for developing countries and countries with weak institutions, as the transfer of information can be favourable or destructive to the well-being of the country of origin depending on the type of norms and values that are remitted. Not only does it emphasize the importance of the social integration of emigrants in their host communities, but it also stresses that migrants are an important tool for encouraging democratization, gender equality and social change in general. Identifying the channels of the cultural transmission remains a crucial task in order to make effective use of the existence of social remittances. 


\section{References}

Agrawal, A., Kapur, D., McHale, J., Oettl, A., (2011). 'Brain drain or brain bank? The impact of skilled emigration on poor-country innovation.' Journal of Urban Economics 69, 43-55.

Aleksynska, M., and Peri, G. (2014). 'Isolating the network effect of immigrants on trade.' The World Economy, 37(3), 434-55.

Alesina, A., Harnoss J., and Rapoport, H. (2016): Birthplace diversity and Economic Prosperity, Journal of Economic Growth, 21: 101-38.

Bahar, D., R. Hausmann, and C.A. Hidalgo. (2014) 'Neighbors and the Evolution of the Comparative Advantage of Nations: Evidence of International Knowledge Diffusion?' Journal of International Economics 92, no. 1: 111-23.

Bahar, D., Hauptmann, A., Özgüzel, C., and Rapoport, H. (2017) 'Diasporas, return migration and comparative advantage: a natural experiment of Yugoslavian refugees in Germany', Mimeo, Paris: Paris School of Economics.

Bahar, D. and Rapoport H. (2018). 'Migration, knowledge diffusion and the comparative advantage of nations', forthcoming in The Economic Journal.

Barr, A., and Serra D. (2010): 'Corruption and culture: An experimental analysis.' Journal of Public Economics 94,11: 862-69.

Barsbai, T., Rapoport, H., Steinmayr, A., and Trebesch, C. (2017). 'The effect of labor migration on the diffusion of democracy: evidence from a former Soviet Republic'. American Economic Journal: Applied Economics, 9(3), 36-69.

Batista, C., and Pedro C. Vicente. (2011) 'Do migrants improve governance at home? Evidence from a voting experiment.' The World Bank Economic Review (2011): lhr009.

Beine, M., Docquier, F., and Rapoport, H. (2001). 'Brain drain and economic growth: theory and evidence'. Journal of Development Economics, 64(1), 275-89.

Beine, M., F. Docquier and H. Rapoport (2007). 'Measuring international skilled migration: new estimates controlling for age of entry', World Bank Economic Review, 21, 2: 249-54.

Beine M., Docquier, F., and Rapoport, H. (2008). 'Brain drain and human capital formation in developing countries: winners and losers.' The Economic Journal, 118(528), 631-52.

Beine M., F. Docquier, M. Schiff, (2013), 'International Migration, Transfer of Norms, and Home Country Fertility', Canadian Journal of Economics 46 (4), 1406-30.

Bertoli, S., and Marchetta, F. (2015). 'Bringing It All Back Home-Return Migration and Fertility Choices.' World Development 65 (2015): 27-40.

Bhagwati, J., and Hamada, K. (1974). 'The brain drain, international integration of markets for professionals and unemployment: a theoretical analysis.' Journal of Development Economics 1.1 (1974): 19-42.

Bisin, A., and Verdier, T. (2000): 'Beyond The Melting Pot': Cultural Transmission, Marriage, And The Evolution Of Ethnic And Religious Traits.' QJE, 955-88.

Breschi, S., Lissoni, F., (2009) 'Mobility of skilled workers and co-invention networks: an anatomy of localized knowledge flows.' Journal of Economic Geography 9, 439-68.

Cain, B., R. Kiewiet, C. Uhlaner (1991). 'The Acquisition of Partisanship by Latinos and Asian Americans', American Journal of Political Science, 35(2), 390-422. 
Chand, S. and Clemens, M. (2008). 'Skill migration and skill creation: evidence from a quasiexperiment in the Pacific'. Working Paper. Washington, DC: Center for Global Development.

Chauvet, L. and Mercier, M. (2014). 'Do return migrants transfer political norms to their origin country? Evidence from Mali.' Journal of Comparative Economics 42.3 (2014): 630-51.

Clingingsmith, D., A. I. Khwaja, and M. Kremer (2009). 'Estimating the Impact of the Hajj: Religion and Tolerance in Islam's Global Gathering' Quarterly Journal of Economics, 124(3), 1133-70.

Combes, P.-Ph., Lafourcade, M., and Mayer, T. (2005). 'The trade creating effects of business and social networks: evidence from France' Journal of International Economics, 66, 1: 1-29.

Daudin, G., R. Franck and H. Rapoport (2016). 'The cultural diffusion of the fertility transition: evidence from internal migration in 19th century France'. Working Paper No 5866, April 2016. Munich: CESifo.

Docquier, F. and H. Rapoport (2012) 'Globalization, brain drain and development' Journal of Economic Literature, September. 681-730.

Docquier, F., E. Lodigiani, H. Rapoport and M. Schiff (2016). 'Emigration and Democracy', Journal of Development Economics, 120: 209-23.

Fargues, P. (2006). 'The demographic benefit of international migration: Hypothesis and application to Middle Eastern and North African contexts' World Bank Publications Vol. 4050. Washington, DC: World Bank.

Felbermayr, G.J. and B. Jung (2009). 'The pro-trade effect of the brain drain: sorting out confounding factors', Economics Letters, 104, 2: 72-75.

Felbermayr, G. and F. Toubal (2012). 'Revisiting the trade-migration nexus: evidence from new OECD data', World Development, 40, 5: 928-37.

Foley, C. F., and W. R. Kerr (2012). 'Ethnic innovation and US multinational firm activity', Management Science.

Gaillard, J. and Gaillard, A.M. (1997). 'The international mobility of brains: exodus or circulation?', Science Technology and Society, 2, 2: 195-228.

Gibson, J., and D. McKenzie (2011). 'Eight Questions about Brain Drain', Journal of Economic Perspectives, 25, 3: 107-28.

Gould, D. (1994). 'Immigrants Links to the Home Countries: Empirical Implication for U.S. bilateral Trade Flows', Review of Economics and Statistics, 76, 2: 302-16.

Head, K. and J. Reis (1998). 'Immigration and Trade Creation: Econometric Evidence from Canada', Canadian Journal of Economics, 31: 47-62.

Jaffe, A.B., Trajtenberg, M., Henderson, R., (1993). 'Geographic Localization of Knowledge Spillovers as Evidenced by Patent Citations.' The Quarterly Journal of Economics 108, 577-98.

Javorcik, B.S., C. Ozden, M. Spatareanu and I.C. Neagu (2011). 'Migrant Networks and foreign Direct Investment'. Journal of Development Economics, 94, 2: 151-90.

Kerr, W.R., (2008). 'Ethnic Scientific Communities and International Technology Diffusion'. Review of Economics and Statistics 90.3, 518-37.

Kerr, W. and S. Kerr (2017). 'Global Collaborative Patents'. Economic Journal, forthcoming.

Koenig, P. (2009). 'Immigration and the export decision to the home country.' Working Paper No 2009-31. Paris: Paris School of Economics. 
Kugler, M. and H. Rapoport (2007). 'International labor and capital flows: complements or substitutes?', Economics Letters, 94, 2: 155-62.

Kugler, M., O. Levintal, and H. Rapoport (2017). 'Migration and cross-border financial flows', forthcoming in World Bank Economic Review.

Levitt, P. (1998). 'Social remittances: Migration driven local-level forms of cultural diffusion.' International migration review (1998): 926-48.

Lodigiani, E. (2016). 'The effect of emigration on home-country political institutions'. IZA World of Labor, forthcoming.

Lodigiani, E. and S. Salomone (2015). 'Migration-Induced Transfers of Norms: The Case of Female Political Empowerment.' Working Paper No 19. Venice: Department of Economics $\mathrm{Ca}^{\prime}$ Foscari University of Venice.

Luttmer, E. F. P., and M. Singhal (2011). 'Culture, Context and the Taste for Redistribution', American Economic Journal: Economic Policy, 3(1): 157-79.

Marchetta, F. (2012). 'Return migration and the survival of entrepreneurial activities in Egypt.' World Development 40.10 (2012): 1999-2013.

Meyer, J.-B. (2001). 'Network approach versus brain drain: lessons from the Diaspora, International Migration', 39, 5: 91-110.

Miguélez, E. (2017). 'Inventor Diasporas and the Internalionalization of Technology'. World Bank Economic Review, forthcoming.

Miyagiwa, K.. (1991). 'Scale economies in education and the brain drain problem.' International Economic Review: 743-59.

Mountford, A. (1997). 'Can a brain drain be good for growth in the source economy?'. Journal of Development Economics, 53: 287-303.

Ortega, F. and G. Peri (2014). 'Openness and income: the role of trade and migration'. Journal of International Economics, 92, 2: 231-51.

Parsons, C. and P.-L. Vezina (2017). 'Migrant networks and trade: the Vietnamese boat people as natural experiment'. Economic Journal forthcoming.

Pérez-Armendariz, C. and D. Crow. (2010). 'Do Migrants Remit Democracy? International Migration, Political Beliefs, and Behavior in Mexico.' Comparative Pol. Studies 43(1):119-48

Pfutze, T. (2012). 'Does migration promote democratization? Evidence from the Mexican transition.' Journal of Comparative Economics 40.2: 159-75.

Rapoport, Hillel (2016). 'Migration and globalization: what's in it for developing countries?', International Journal of Manpower, 37, 7, 2016: 1209-26.

Rapoport, Hillel (2017). 'Migration et développement: les externalités de la diaspora'. Revue d'Economie du Développement, 25, 1, 2017 : 31-61.

Rapoport, Hillel, Sulin Sardoschau and Arthur Silve (2017). 'International Migration and Cultural Convergence', Mimeo. Paris: Paris School of Economics.

Rauch, J. E. and V. Trindade (2002). 'Ethnic Chinese networks in international trade'. Review of Economics and Statistics, 84, 1: 116-30.

Rauch, J. E. and A. Casella (2003). 'Overcoming informational barriers to international resource allocation: Prices and Ties'. Economic Journal, 113, 484: 21-42. 
Shain, Y. (1999). 'Marketing the American creed abroad: Diasporas in the US and their homelands'. Cambridge: Cambridge University Press

Shreshta, S. A. (2017). 'No Man Left Behind: Effects of Emigration Prospects on Educational and Labour Outcomes of Non-migrants'. Economic Journal, 127, 600: 495-521.

Singh, J., Marx, M., (2013). 'Geographic Constraints on Knowledge Spillovers: Political Borders vs. Spatial Proximity'. Management Science 59, 2056-78.

Spilimbergo, A. (2009). 'Democracy and Foreign Education.' American Economic Review 99(1): 52843.

Steingress, W. (2015). 'The Causal Impact of Migration on US Trade: Evidence from a Natural Experiment'. Discussion Paper No 9058, May. Bonn: IZA.

Thompson, P., Fox-Kean, M., (2005). 'Patent Citations and the Geography of Knowledge Spillovers: A Reassessment'. The American Economic Review 95, 450-60.

Todaro, M. (1996). Economic Development, Cambridge: Cambridge University Press, 5th edition.

Tong, S.Y. (2005). 'Ethnic Networks in FDI and the Impact of Institutional Development'. Review of Development Economics, 9, 4: 563-80. 